\title{
N.T. Wright's New Perspective on Paul: What implications for Anglican doctrine?
}

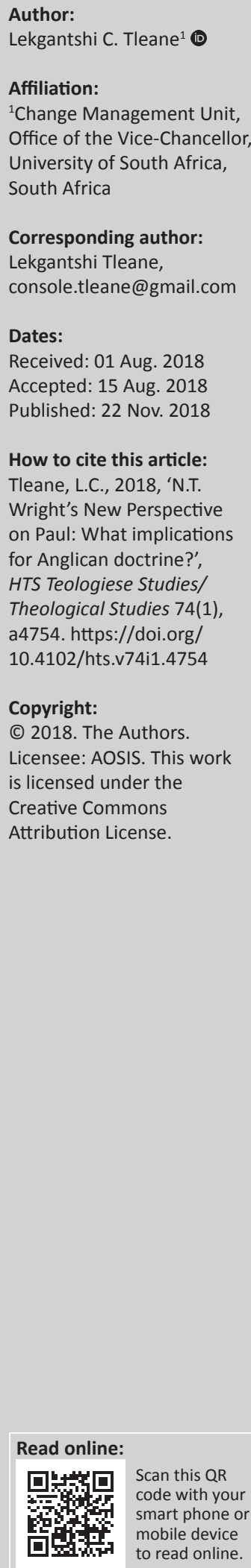

\begin{abstract}
The entrance of New Perspectives on Paul as a reinterpretation of what the Apostle Paul wrote evoked varied responses, especially within the evangelical circles of the Reformed community. Interestingly, one of the foremost thinkers within the New Perspectives on Paul school is the retired Anglican Bishop and New Testament scholar Nicholas Thomas Wright. Wright's scholarship is interesting to study, given his prominence within evangelical circles in general and his respectable standing within the Anglican Communion in particular. Yet there does not appear to be any coherent response or position from the Anglican Communion in relation to the New Perspectives on Paul, let alone Wright's views. The key question posed in this article is whether Wright's writings might influence Anglican doctrine. The Communion's soteriological doctrine as contained in Articles XI, XII and XIII of the Thirty-nine Articles of Religion may be understood to affirm the 'old perspective on Paul' and its 'justification by faith only, and not by good works' approach. Finally, the article examines the complexities that Wright's influence might have, in the form of a possible shift in doctrinal posture, and the implications for church structures that such a shift might necessitate.
\end{abstract}

\section{Introduction}

The New Perspectives on Paul was effectively introduced during the mid-1970s. It is the reinterpretation of what the Apostle Paul wrote, especially the letters to the Romans, Galatians and Philippians. The focus is on Paul's views on the roles of justification and the law in salvation and whether he was against the law per se or if his objections were limited to the imposing of 'works of the law' - circumcision, observance of ritual (specifically the Sabbath) and dietary regulations - on gentile Christians.

This new approach challenges the established Lutheran interpretation of Paul, which saw '... a rupture with the whole law in the apostle's epistles' (Stoychev 2011:49). The key question that New Perspectives on Paul scholars pose, and attempt to answer, is: 'does the apostle declare himself against the whole law or only against the ritual observation of the law (Stoychev 2011:49)?'

The plural 'perspectives' will be used throughout this article to emphasise the fact that the approach to Paul's writings is not a homogenous school of thought. For this article we examine Nicholas Thomas Wright's perspective, of course in relation to other perspectives. The decision to focus on Wright was motivated by two reasons. Firstly, by his own admission, Wright is an evangelical theologian. This presents a peculiar typification as some of the critics of the New Perspectives on Paul argue that the new approach is a revision of pre-Reformation Roman Catholic arguments (Farnell 2005:190). In addition, the received wisdom seems to suggest that evangelicals are, overall, adherents of the Lutheran approach to Paul's writings (Bird 2005).

The second reason for choosing Wright is that he is a prominent former Bishop of Durham, within the Church of England. This raises the question on what the response to the New Perspectives on Paul from the Anglican Communion might be, especially viewed against the inevitable implications on Articles XI, XII and XIII of the Articles of Religion of the Anglican Communion (Episcopal Church in the US 1801). Wright's views are therefore examined against the backdrop of his Anglicanism and how his New Perspective on Paul might, or might not, gain traction within the Communion, and perhaps change its doctrine.

In addressing these questions, this article examines whether such an interaction between Wright's views and those of the Communion might find a platform for reflection through some form of a centralised authority on doctrine. 


\section{The New Perspectives on Paul: The beginnings}

The New Perspectives on Paul are, according to Garlington, '... an attempt to understand Paul within his own context' (Garlington 2004:1) or, simply put, discovering the 'real Paul'. The 1977 book Paul and Palestinian Judaism: A Comparison of Patterns of Religion, by Sanders (1977), is broadly regarded as the catalyst to the New Perspectives on Paul. It was this book, which O'Brien (2004) described as 'ground-breaking', that had the effect of changing:

... the course of subsequent Pauline scholarship, and forced
recent interpreters to rethink fundamentally the nature of the
Jewish opposition that the apostle faced in his churches as well
as the substance of the criticisms that he raised against it. (p. 249)

For others, Sanders' book led to '... a collapse of Reformation consensus regarding Paul's view of the law in the learned centers of theology' (Farnell 2005:204). An interesting twist in Sanders' views is noted by Martin in his book Christ and the Law in Paul (Martin 2001). Martin notes that in 1978 Sanders argued that Paul made a distinction between the ritual law, which he (Paul) rejected, and the moral laws, which he embraced and promoted (ibid). Yet Martin observes that by 1983 Sanders no longer argued that there was such a distinction, stating that he (Martin) agreed with the Sanders' 1978 argument, while disagreeing with his later 1983 view (ibid).

Providing the context that prevailed during Paul's time, Brown and Meier postulate four soteriological approaches of the 1st-century Christian community, which crystallised into groups (Brown \& Meier 1982). The first group comprised Jewish Christians and their followers and insisted on the full observance and adoption of Mosaic Law. This included circumcision; hence the group came to be known as the 'circumcision group', or the Judaisers. The term 'Judaise' (meaning 'to convert to a Jewish life') is not explicitly used in Bible translations. The biblical text usually referenced is Galatians 2, which relates the Incident at Antioch, specifically verse 14. Another reference to the Judaisers could be those referred to as 'the party of the Pharisees', in Acts15:5. The term 'Judaisers' is nonetheless used in some academic circles, for instance by Murray (2004), who argues that:

from Paul's perspective, by withdrawing from Gentile table fellowship, Peter was sending a message to the Gentile believers of Antioch. The message to Antiochene Gentile Christians was that they were to judaize. (p. 33)

The second group comprised Jewish Christians and Gentiles (led by the Apostle James) who did not insist on Mosaic Law but instead deemed the observance of the seven Noahide Laws (Genesis 9) - do not deny God; do not blaspheme God; do not murder; do not engage in illicit sexual relations; do not steal; do not eat of a live animal; and establishing a legal system to keep the law - as sufficient for acceptance as a follower of Jesus. An example of this group is found in Acts 15, during the Council in Jerusalem, which was called to resolve questions relating to whether Gentile followers of
Jesus were supposed to adopt Jewish laws. The Apostle James sets down the Noahide Laws in Acts 15:13-21.

The third group comprised Paul and his followers, who did not insist on circumcision or the observance of Jewish food laws. Examples of the 'Paul group' can be found in various portions of Galatians, Philippians and Romans, as well as in Acts 15:2.

The last and fourth group comprised Hellenised Jews who attached no significance to Jewish law, cults or feasts but also felt discriminated against by Hebraic Jews. Examples of these groups can be found in Acts 6:1-6 and Acts 9:29.

Wright elaborates on the context within which Paul was writing and what he was against. He mentions, though briefly, three scenarios, which are intertwined and which he observes have been played against each other, and warns that that should not be the approach. These are '... the cosmic, as in Romans 8; the ecclesiological, as in his constant emphasis on the unity of Jew and Gentile in Christ; and the political' (Wright 2013:33; [author's own italics]). The 'political' can be understood to have been Paul's attack on Jewish ethnic exclusiveness.

\section{Modern evolution and meaning}

In the following discussion on Sanders, I rely on the work of Stoychev (2011). In Sanders' view, as summarised by Stoychev, all branches of Judaism view Israel's connection with God as a fruit of blessed activity in the establishment of the covenant with his people. Submission to the law is an adequate answer to God's grace. On the other hand, salvation is not deserved or reached by performance, which may not even be called merit. It is rather an act of God's grace. Therefore, submission to the law in Judaism is not a means of entering the covenant or gaining special connection to God. It is, instead, a way of maintaining the covenant connection with God; in other words, it is a means to stay within the covenant.

It is on the basis of the above analysis that Sanders coined the term - which he used for how Judaism treated the law 'covenantal nomism' (derived from the Greek word nómos [vónoc], which is understood to mean 'custom' or 'law'). This requires obedience to the commandments, while providing a means of atonement for transgressions. Thus, for Sanders, Paul's dispute against Judaism is not about the problem of 'deeds', per se, or the 'works of the law'. It is about his soteriology and insistence that Gentiles should be accepted into God's nation without having to adopt the Jewish nómos.

Dunn's (1990) entry into the debate was to identify the problem with Judaism as not being its legalism. He identifies its 'extreme state or form of ethnocentrism' as the main problem. Paul's struggle is specifically against the 'works of the law', which Dunn identifies as (1) requirement for male circumcision, (2) observance of Sabbath and (3) dietary regulations. This postulation by Dunn has since become one 
of the central arguments of the New Perspectives on Paul, with which Wright agrees.

It was Dunn who coined the phrase 'New Perspective on Paul' during his 1982 Manson Memorial Lecture at the University of Manchester, reproduced as 'A Light to the Gentiles' or 'The End of the Law: The Significance of the Damascus Road Christophany for Paul', in the book Jesus, Paul and the Law: Studies in Mark and Galatians (Dunn 1990).

Szabados argues that the focus of the 'new perspective' centres around Romans 3:21-26 (Szabados n.d.). Indeed, a reading of the three major proponents of the new perspective Sanders, Dunn and Wright - does indicate that they do place some emphasis on those verses, although not exclusively. In fact, Wright makes the point that his supposed entry into the new perspective debate was through a re-examination of the Epistle to the Romans (Wright 2006).

Various themes and arguments can be extrapolated from the New Perspectives. Duncan (2008) suggests three. Firstly, the Judaism of Paul's day is seen as having not been a religion of self-righteousness that taught salvation by merit. Secondly, Paul's disputation with the Judaisers was not about a 'works-righteousness' view of salvation, over and against the Christian view of salvation by grace. Thirdly, Paul's concern was for the full recognition of Gentiles within the church. Hence, according to Duncan, justification is about ecclesiology rather than soteriology; it is about who is part of the covenant community (the early church at the time) and what are its boundary markers, rather than about how a person stands before God (Duncan 2008).

Once an understanding of the above has been achieved the New Perspectives on Paul develop four avenues of analysis. Firstly, they attempt to have a better understanding of Paul and the early church in their original context. This aim is identified by Farnell (2005), who argues that the New Perspectives is located within the historical-critical method.

The second aim is to vindicate Paul and early Christianity from the charge of anti-Semitism. This would, however, be a wrong interpretation of Paul, a major error committed by Martin Luther, who unwittingly led himself into what some regard as a form of anti-Semitism, as reflected in his rather disturbing and unfortunate treatise, On the Jews and Their Lies (Luther 1543).

Thirdly, the New Perspectives are aimed at resolving the theological debate between Catholic and Protestant interpreters of Paul. This, however, does not seem to have been achieved. Whereas Catholics in general may agree with the New Perspective positions (Barber 2013), especially because of their affirmation of James' assertion in James 2:14-16, in which he criticises 'faith alone' without the 'works' argument as he asserts that '... faith without works is also dead', there are continuing debates within Reformation circles around what Paul really stood for, and against.
Lastly, the New Perspectives aim to articulate an understanding of justification that has inherent social dimensions and therefore secure a better theological foundation for social justice and ecumenism among evangelical interpreters of the scriptures.

\section{N.T. Wright's 'New Perspective on Paul'}

Despite standing alongside Sanders and Dunn as one of the pioneers of the New Perspectives on Paul approach, the specific focus on Wright is important for a third reason, in addition to him being an evangelical and a prominent former Anglican bishop. Wright's 'perspective' is, by his own assertions, different from the perspectives of both Sanders and Dunn (Wright 2006). Two critical areas of study stand out in Wright's New Perspective on Paul - justification and the law.

\section{On justification}

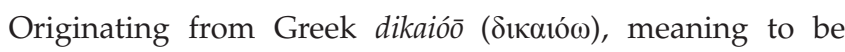
'right' or having 'judicial approval', justification is a '... declaration that somebody is in the right' (Wright 1980:14). Used in the Old Testament to denote God's actions to restore Israel's fortunes from oppression, justification is redefined in the New Testament, with the Jesus ministry to the poor and humble, as well as questionable characters (e.g. the tax collector) (Wright 1988). Jesus dies on the cross, where there is '... grace incarnate' (Wright 1980:16), to represent all people - the rich and the poor.

Justification presupposes two things: sin and grace. Where there is no sin, there is no need for justification. Hence, in its Hebrew law court (judicial) use, where there is no offense, there is no 'pardon' or 'acquittal'; there is simply no case to be answered to. Similarly, grace needs to be raised by God (ibid). Wright (2013) went on to write later that justification is:

... God's declaration that a person is in the right; that is, (a) that their sins have been forgiven, and (b) that they are part of the single covenant family promised to Abraham. (p. 260)

For Wright, justification happens at two levels, or stages. First, justification happens in the future, meaning that it follows a person's life and how they would have conducted themselves, that is, '... the basis of the entire life a person has led in the power of the Spirit ...' (ibid). It therefore comes as 'judgement'. Second:

... it occurs in the present as an anticipation of that future verdict, when someone, responding in believing obedience to the 'call' of the gospel, believes that Jesus is Lord and that God raised him from the dead. (p. 260)

The latter constitutes what, in Wright's view, is 'justification by faith', that is, '... the anticipation in the present of the verdict which will be reaffirmed in the future' (ibid). Therefore, justification is not 'how someone becomes a Christian'. Rather, it is God's declaration about the person who has just become a Christian. 
The entire Christian mission is, therefore, built on redefining God's covenant with, and for the people. For Wright, Paul's message can be described in five points. Firstly, justification is about covenant membership. The membership is for all of Abraham's children, irrespective of race, ethnicity or moral background, as God did indeed make a promise of inclusivity in Genesis 22:17-18.

Secondly, the death and resurrection of Jesus is the basis of justification. God deals with humanity's sinfulness through the death of Jesus on the cross.

Thirdly, faith in Jesus anticipates the final judgement based on 'total life'. We will return to this point later when we consider Wright's treatment of the 'works', not just the 'works of the law'. Thus, 'faith itself is the sign of God's lifegiving work, by his spirit and what God has begun he will complete' (ibid).

Fourthly, the church, the 'new Israel', is established as a new entity through justification, transcending all racial and social barriers. Gentiles did not have to adopt Jewish laws and customs to be accepted into the 'new covenant'.

The last point that Wright makes is that justification has nothing to do with good behaviour, meaning the observance of the 'works of the law'. 'Good behaviour' here should be understood as adherence to the law and should not be confused with an appropriate and morally upright life.

On the other hand, Paul's criticism against the 'works of the law' is not about those who-especially Jews-tried to live up to the standards required by the law. Instead, it is against the law being used as a boundary marker and condition of acceptance. What then, is Wright's understanding of the faith that Paul says will justify the believer? This is important to understand before we can turn our attention to how he (Paul) understood the law and how Wright reads him.

In his exposition of faith Wright makes a distinction between faith as acquired through birth or merit (by or for Jews) and faith that is a gift from the Holy Spirit; an act that Christians embrace when welcoming Jesus into their lives and living according to his commands. Wright (2013) writes the following about faith:

Faith is not something someone does as a result of which God decides to grant them a new status or privilege. Becoming a Christian, in its initial moment, is not based on anything that a person has acquired by birth or achieved by merit. Faith is itself the first fruit of the Spirit's call. And those thus called, to return to Philippians 1:6, ${ }^{1}$ can be sure that the one who began a good work in them will complete it at the day of Christ. (p. 257)

Wright (2013) proceeds further to develop the link between faith and justification:

\footnotetext{
1.Philippians 1:6: 'I am confident of this, that the one who began a good work among you will bring it to completion by the day of Jesus Christ' (Footnote text added by current author for clarity).
}

$\ldots$ if we are thinking Paul's thoughts after him, we are not justified by faith by believing in justification by faith. We are justified by faith by believing in the gospel itself - in other words, that Jesus is Lord and that God raised him from the dead. If, in addition, we believe in justification by faith itself, we believe that, amazingly considering what God knows about us, we are now and for ever part of the family to every member of which God says what he said to Jesus at his baptism: you are my beloved child, with you I am well pleased. (p. 261)

In the above quotation, Wright is emphasising active participation of a Christian in his or her faith in the resurrected Jesus. There is therefore a need to remain faithful and loyal to the path of following Jesus and to live according to the teachings of the Gospel. How then does the law fit into this complexity?

\section{On the law}

Instead of viewing Paul as being anti-Judaism, as the earlier conservative Lutheran view would have had it, Wright argues that Paul remained a thoroughly Jewish scholar. For Wright (2013):

... Paul's critique of Israel is not based on, or productive of, antiJudaism as such, still less anti-Semitism, but involves a far more delicately balanced and nuanced theology which cannot be reduced to such slogans. (p. 246)

Paul is, in Philippians 3, found to be firmly grounded in the Jewish heritage when he criticises Caesar. Thus, for Wright:

\begin{abstract}
... Paul's critique of Caesar's empire was firmly grounded in his Jewish heritage. Discovering the pagan history-of-religions parallels to Paul does not mean suggesting that Paul did not remain a thoroughly Jewish thinker. What he does with the Caesar-cult stems directly from what Isaiah does with the Babylonian cult, which in turn looks back to Deuteronomy's rejection of all paganism in favour of the stern monotheism of the creator and covenant God. The rediscovery in our day of the pagan context and target of Paul's thinking should not mean for one minute a going back on the great gain of the last generation, the rediscovery that Paul was and remained a thoroughly Jewish thinker. (Wright n.d.)
\end{abstract}

Like Dunn, Wright holds that Paul was not against the law per se. As Talbert (2001) notes:

The gist of the new perspective's argument is to move the focus of Paul's theology from grace versus legalism (divine initiative versus human self-sufficiency) to universalism versus ethnic exclusiveness (inclusiveness versus particularism). (p. 13)

What is for Wright an interesting assertion by Paul, which (according to Wright) some adherents of the 'old perspective' find difficult to reconcile, is Romans 2:13, which states: 'For it is not the hearers of the law who are righteous in God's sight, but the doers of the law who will be justified'. Wright emphasises that Paul's insistence was that non-Jewish Christians did not have to adopt, or be made to adopt, Jewish laws, to enter and receive God's calling. On the other hand, those whose deeds are in line with the law in terms of their 'conduct', even if they may not profess by the law, 'will be justified'. 
The above point is amplified when he writes:

... Paul understands faith to be the true fulfilling of the law. The difficult argument of Romans 9:30-10:13 may be summarized thus: the failure of the Jews lay in their abuse of the law as a charter of national privilege, which caused them to reject the Gospel of the crucified Messiah; the law was actually intended to evoke faith. When, therefore, Gentiles come to believe in Jesus Christ, they are in fact fulfilling the law, whether or not they have even heard of it, and they are therefore rightly to be regarded as within the covenant, i.e. they are to be justified. (Wright 1980:25)

Wright reads Paul not to be contradicting the message by Jesus himself when he said in Matthew 5:17: 'Do not think that I have come to abolish the Law or the Prophets; I have not come to abolish them but to fulfil them'. This assertion by Jesus becomes illustrative if we were to agree with Perkins (1978) that the Gospel of Matthew is written for the Jews. The Sermon on the Mount was aimed at correcting some of the Pharisaic distortions.

Having clarified what Paul stood against, Wright shifts his argument to an area where he can be said to be in agreement with the 1978 stance by Sanders as we noted earlier, which was that Paul made a distinction between 'ritual laws' (works of the law) and 'moral laws' (Martin 2001). Wright (2013) writes:

The 'works' in accordance with which the Christian will be vindicated on the last day are not the unaided works of the selfhelp moralist. Nor are they the performance of the ethnically distinctive Jewish boundary-markers (sabbath, food-laws and circumcision). They are the things which show, rather, that one is in Christ; the things which are produced in one's life as a result of the Spirit's indwelling and operation. (p. 254)

Paul argued for tolerance with regards to the 'works of the law', but that the law was necessary for conduct, what Wright refers to as Paul's 'non-negotiables', as espoused especially in 1 Corinthians. Therefore:

... the ones [actions in relation to the law] that were tolerated were the ones that carried the connotations of ethnic boundary lines, and the ones that were not tolerated were the ones that marked the difference between genuine, living, renewed humanity. (Wright 2002)

Wright stresses that Paul was, for instance, strict and intolerant towards sexual immorality and had no place for anger and slander. Critically, Wright addresses himself to the wrong view that '... since we are justified by grace through faith there is no need for life of holiness[sic], and that to insist on one is to smuggle "works" in by the back door' (ibid).

True to his emphasis that scripture should not be read selectively but as a whole, Wright challenges arguments by some that there are inconsistencies within the epistles of Paul, referencing 1 Corinthians, especially Chapter 15, as showing the need to maintain an upright ethical conduct and not adopt moral relativism (Wright 1991:1-7). He writes again in another instance:
When final judgement occurs, it will not be arbitrary; it is not the case that God has made up a list of rules upon some kind of whim. Final judgement will be according to genuine humanness, and genuine humanness is what truly reflects the image of God. (Wright 2002)

Human beings will therefore face judgment in accordance with how they conducted themselves.

Having addressed the need to have a balanced understanding of the conception of the law for Paul as it relates to 'ritual law' and 'moral law', Wright moves on to address what may be viewed as binary approaches that often creep into debates. By articulating Paul's anti-imperialist theology, which is grounded in his Jewish heritage, Wright does not mean that Paul was less critical of the Judaisers who sought to impose the law on non-Jews as a condition for acceptance into a community of believers. He writes:

... neither the recognition that Paul's main target was paganism, and the Caesar-cult in particular, nor the equal recognition that he remained a thoroughly Jewish thinker, should blind us for a moment to the fact that Paul still expressed a thorough critique of non-messianic Judaism. Paul remains at this point on the map of second-temple Judaism: believing that God had acted to remodel the covenant people necessarily entailed believing that those who refused to join this remodelled people were missing out on God's eschatological purpose. (Wright 1998)

Wright addresses another binary that often creeps into contemporary political and academic debates: that of reducing any criticism of the Judaisers' attempt at imposing the law as being, of necessity, anti-Judaism or anti-Semitic. He writes:

As post-holocaust thinkers, we will of course be careful how we say all this. As historians of the first century, we will recognise that it must be said. As Pauline theologians, we will recognise that it contains no shadow, no hint, of anything that can be called anti-Judaism, still less anti-Semitism.

What comes out in Wright's scholarship, a theme that he pursues with passion in most of his writings, is an appeal for a more nuanced reading of Paul, free from the simplistic, rigid and at times reductionist approaches that even some of the New Perspectives theologians themselves adopt. Wright's reading of Paul is complex and attempts to bring out the many facets of Paul's thinking, understood in the contexts that he wrote out of and the many communities that he wrote to.

Having considered Wright's New Perspective on Paul we can now pose the question about the influence that his views might have on the broader Anglican Communion and its doctrinal positions.

\section{Wright's New Perspective and the Anglican Communion}

In a 2005 address to the Auburn Avenue Presbyterian Church, Monroe, LA, US, Wright laments that his writings receive 
attention mainly in the US rather than in his native England. $\mathrm{He}$ also observes that they do not receive much attention within the Anglican Communion (Wright 2005a). This raises a curious contradiction because Wright remains a respected figure within the Communion. For instance, he was, at some stage, a member of two commissions within the Communion that had the potential to influence Anglican doctrine the International Anglican Doctrinal and Theological Commission (the IADTC) and the Lambeth Commission (Wright 2005b). Could Wright use the platforms provided by these two bodies to infuse his ideas?

In an earlier article on the future of Anglicanism, already referenced above, Wright seems to suggest the need for the Anglican Communion to establish formal structures that would consider doctrinal matters (Wright 2002). He writes: 'We may have to renounce our easy-going and informal structures' (ibid). In yet another article he writes:

And of course, I have found myself involved in the troubled situation of our Communion following the disastrous events of 2003. I have grieved at the muddled teaching which has allowed all kinds of confusions about Christian doctrine, behavior and even the nature of Anglicanism to abound, with disastrous consequences. I have shared the frustration of many at the fact that we don't possess the kind of structures that would enable us to deal straightforwardly and clearly with the complex problems that have faced us. (Wright 2008)

The events that Wright is referring to here surround the election of an openly gay priest, Gene Robinson, as Bishop of the Diocese of New Hampshire, within the Episcopal Church of the US in 2003, causing tensions within the Anglican Communion that remain unresolved to this day (BBC News 2012)

The question that needs to be posed considering the above is: what form should the '... structures that would enable us to deal straightforwardly and clearly with the complex problems that face us' take, and what issues may they have to address, in light of Wright's 'perspective on Paul'?

\section{A need to revise some elements of the Thirty-nine Articles of Religion?}

The Thirty-nine Articles of Religion trace their origins to the formulations by Thomas Cranmer and have evolved over time, both in number and content (Cocksworth 1998). They can be regarded as the unifying statement of Anglican faith, in addition to the scriptures, tradition and the creeds. What distinguishes the Articles from other denominational statements of faith is articulated by Cocksworth (1998), who writes:

The Articles should not be seen as the Church of England's equivalent to the Augsburg Confession or to the Heidelberg Catechism and certainly not to the conciliar decrees of the Roman Catholic Church. In terms of one of England's favorite sports, they evolved and have acted as boundaries within which varied players may take part in a game of cricket, rather than the precise, detailed, and at times confusing rules of play. Indeed, as with the boundaries in the game of cricket, they have had a habit of contracting and expanding according to where the match is being played and the age and inclination of the participants. However, just as there comes a point when the English seem to know that the boundary has been either so reduced or so enlarged that the game of cricket has been made impossible, so the psyche of the Church of England seems to be able to sense that some interpretations of the Articles have been either so extended or so restricted that they have ceased to be credible parameters of Anglicanism. (p. 199)

It can be argued therefore, following Cocksworth, that perhaps the Articles 'have ceased to be credible parameters of Anglicanism' and may therefore need some revision.

John Rodgers Jr (2013) also assists us to situate an assessment of the Articles when he introduces his own analysis as follows:

Since the Thirty-Nine Articles of Religion claim to be biblical, it is important to determine both what the Articles teach about salvation and whether what they teach is, in fact, biblical. (p. 115)

How then do the Articles, or at least some of them, 'measure up' against Wright's 'new perspective on Paul'?

Three of the Articles - Articles XI, XII and XII - are relevant for the purposes of our review as they address themselves to Paul's treatment of justification and the law. They are Pauline in their composition.

\section{Article XI reads:}

We are accounted righteous before God, only for the merit of our Lord and Saviour Jesus Christ by Faith, and not for our own works or deservings. Wherefore, that we are justified by Faith only, is a most wholesome Doctrine, and very full of comfort, as more largely is expressed in the Homily of Justification. (Anglican Online n.d.)

It can be argued that whereas this Article does adequately reflect the essence of Paul's writings, Wright might express caution against the notion that Christians should not endeavour to lead holy lives. Wright's catechetical advice could therefore be to insist that Christians should, as they affirm their faith as being adequate and a gift from God, also ensure that they observe what he termed the 'non-negotiable' moral laws that Paul laid down. It could mean that Article XI requires some form of expansion, to insert the necessity of observing the 'moral laws'.

The deficiency of Article XI appears to be addressed in Article XII (following). This might suggest that the compilers (Cranmer and his successors) were aware of the possible limitations of Article XI and how it could be misread.

\section{Article XII reads:}

Albeit that Good Works, which are the fruits of Faith, and follow after Justification, cannot put away our sins, and endure the severity of God's judgment; yet are they pleasing and acceptable to God in Christ, and do spring out necessarily of a true and lively Faith insomuch that by them a lively Faith may be as evidently known as a tree discerned by the fruit. 
The major limitation with this Article is that it fails, in the light of Wright's agreement with Dunn in regard to the understanding of what 'works of the law' means, to distinguish observance of the 'works of the law' circumcision, Sabbath and dietary regulations - and the 'law in general', including 'moral laws' as articulated earlier.

It may be necessary for the Article to be elaborated on by making a distinction that the 'Good Works' do not mean the 'works of the law' but that they refer to the striving for holiness and good conduct that Wright insisted Paul identified as being 'non-negotiable'.

In a similar vein, Article XIII seems to give an impression of turning Christians indifferent to exerting effort to 'do good'. This article was clearly written with the observance of the 'works of the law' in mind, which Wright agrees is where Paul preached tolerance.

\section{Article XIII reads:}

Works done before the grace of Christ, and the Inspiration of his Spirit, are not pleasant to God, forasmuch as they spring not of faith in Jesus Christ; neither do they make men meet to receive grace, or (as the School-authors say) deserve grace of congruity: yea rather, for that they are not done as God hath willed and commanded them to be done, we doubt not but they have the nature of $\sin$.

What may be required in the case of Article XIII is for a distinction to be made that the 'Works' referred to here are the 'works of the law'. Such a distinction will assist Anglicans to understand, as with the other two Articles referred to previously, the 'good works', which is the moral conduct that Christians should follow and which are 'non-negotiable', as being distinguishable from the 'works of the law', which are not compulsory for Christians to adopt or follow.

It can be argued that the three Articles examined above may be found to represent some remnants of the conservative Lutheran thinking that went into the Anglican doctrine. It may therefore be necessary, as those like Wright may strive to inject 'new perspectives on Paul' within the Anglican Communion, for some of the Articles of Religion to be revised. However, will that be possible?

\section{Towards an Anglican magisterium?}

The nature of teaching authority within the Christian church is varied. Practices range from centralised authority, as found within Roman Catholicism, through to loose traditions like those of the Presbyterian and Baptist denominations; and non-existence of such authority within the Pentecostal groups.

There are both benefits and weaknesses in whatever form of teaching authority a denomination may adopt. Centralised teaching authority may mean that some form of dogma emerges, where new interpretations of scripture may be stifled. At the same time, a dogmatic approach may mean that there is uniformity and clarity and therefore no 'confusion' in the teachings of a denomination. On the other hand, 'loose traditions' may mean that believers have space to develop their own rich interpretations of the scriptures, of course with some guidance, and apply such on their existential conditions. The inherent weakness with such an approach, however, may arise when there are such diverse interpretations of the scriptures that chaotic scenarios develop.

Unlike the Roman Catholic Church, which has the magisterium, the teaching authority of the Roman Catholic Church exercised mainly by the Pope and Bishops, or such bodies as may be appointed and given authority by the Pope (like the Vatican's Congregation for the Doctrine of Faith), the Anglican Communion does not have a centralised authority that lays down the central doctrine of the Communion (Avis 2007:203).

The closest that Anglicanism has to a loose 'magisterium' seems to exist in the form of the four instruments of Anglican Communion unity. These are: the Archbishop of Canterbury as the spiritual head of the Communion; the Lambeth Conference as a consultative conference of all the bishops of the Communion; the Anglican Consultative Council, which is attended by selected bishops, clergy and laity; and the Primates Meeting, which is a meeting of the Archbishops as heads of the various provinces of the Communion (Radner \& Turner 2006).

The foregoing demonstrate the uniqueness of Anglicanism and what has shaped its identity over the years of its existence: the Elizabethan formulary of via media - occupying the middle strata, both in terms of organisation and doctrine, between the hierarchised and centralised Roman Catholicism on the one hand, and dehierarchised and decentralised Protestantism on the other. The inclusion of the laity in the Anglican Consultative Council demonstrates the 'democratic' practices within Anglicanism, which may be lacking within Roman Catholicism.

The 2008 resolution of the Lambeth Conference to establish the Anglican Covenant was, arguably, a step towards establishing a body with semblances of the magisterium (Lambeth Conference 2008). This attempt has however been met with scepticism at best and criticism at worst (BBC News 2012).

Apart from the foregoing there is the IADTC. Established in 2001, the IADTC held a few meetings and produced several important reports on some matters of doctrine from 2001 until 2008 (International Anglican Doctrinal and Theological Commission 2008). The adoption of any recommendations from the IADTC by dioceses is nonetheless optional. Different provinces, and even dioceses within the provinces, may choose to adopt or rejects recommendations from the IADTC.

The preceding observations do not however imply that the Anglican Communion lacks a coherent theology, only that its approach to doctrine allows for more diversity, surely better 
than the Roman Catholic Church. Similarly, it is not claimed here that the Roman Catholic Church does not allow for diversity within its established doctrine and dogma, only that the Vatican is able to hand down coherent doctrinal positions, the other side of the coin being when the Congregation for the Doctrine of Faith, for example, places some limits to diversity of thought.

Given the inherent weaknesses of decentralisation others within the Communion, though still a minority, have started advocating for a centralised teaching authority. Australian Anglican priest Peter Carell has argued in favour of an Anglican magisterium. He writes:

I do understand that around the Communion a number of people, for various reasons, feel strongly that a body with authority to declare what is our common doctrine and practice and what is not, is a bad thing. I simply find it inescapable that continuing lack of this body means we will continue to fragment and divide as a Communion. I think that is a bad thing too! (Carell 2010)

Wright's and Carell's voices might be minority views. They however point to a fundamental consideration that the Communion must, at some stage, consider. It might well be that the establishment of some form of a centralised teaching authority can address the gap that currently exists, to assist the Communion to integrate recent doctrinal questions such as those arising from the writings of those like Wright. Whether such an authority will be formed in the not-toodistant future is best left to the evolution of the Communion, which will be assisted by debates and reflection.

\section{Conclusion}

What has come out clear in this article is that the New Perspectives on Paul is a revisiting, rereading and reinterpretation of Paul's epistles, especially as he addresses soteriological questions.

The picture that we have attempted to draw in this article is, however, much more complex than reality can turn out to be. The church as a whole, and various denominations, not least the Anglican Communion, take long periods of time to consider and revise doctrinal positions. Equally, church structures take a long time to undergo change. The church is characterised by a stubborn adherence to tradition that has, on the one hand, made the Christian faith enduring and resilient over many centuries, while stifling the ability to respond speedily and adequately to change.

Whether the frustrations expressed by those like Wright who may wish to see an end to the inability to resolve pertinent questions, or the warning by those like Carell, who express the concern that the lack of a central authority may lead to more challenges in the light of the emergent issues, are all enough to propel the Communion to the creation of such an authority, all that remain matters of speculation and theological debates and not necessarily accurate scientific prediction.
It may well also be that the Communion is faced with difficult and arguably 'more pressing matters' that pose the real threat of splitting it and need urgent attention, such as the complex issue of gay marriages (Stevens 1989; Vanderbeck et al. 2011), than to consider matters of doctrinal debate like the New Perspectives on Paul. Yet the Communion will, at some stage, and as advancements are made in theological study, be confronted with the need to revisit its doctrines.

\section{Acknowledgements Competing interests}

The author declares that he or she has no financial or personal relationships which may have inappropriately influenced him or her in writing this article.

\section{References}

Anglican Online, (n.d.), Articles of religion, viewed 10 April 2017, from http:// anglicansonline.org/basics/thirty-nine_articles.html

Avis, P., 2007, 'Anglican ecclesiology', in G. Mannion \& L.S. Mudge (eds.), The Routledge companion to the Christian Church, pp. 202-216, Routledge, New York.

Barber, M.P., 2013, 'A catholic perspective: Our works are meritorious at the final judgment because of our union with Christ by Grace', in R.N. Wilkin, T.R. Schreiner, J.D. Dunn \& M.P. Barber (eds.), Four views on the role of works at the final judgment, pp. 161-184, Zondervan, Grand Rapids, MI.

BBC News, 2012, Half of the Church of England's dioceses reject unity covenant, viewed 10 April 2017, from http://www.bbc.com/news/uk-17500144

Bird, M.F., 2005, 'When the dust finally settles: Coming to a post-new perspective', Criswell Theological Review 2(2), 57-69.

O'Brien, P.T., 2004, 'Was Paul a covenantal nomist?', in D. Carson, P.T. O’Brien \& M.A. Seifrid (eds.), Justification and variegated Nomism Volume II: Paradoxes of Paul, pp. 249-296, Baker Academic, Grand Rapids, MI.

Brown, R.E. \& Meier, J.P., 1982, Antioch and Rome: New testament cradles of Catholic Christianity, Paulist Press, New York.

Carell, P., 2010, Towards an Anglican Magisterium, viewed 06 April 2017, from http:// anglicandownunder.blogspot.co.za/2010_09_01_archive.html

Cocksworth, C.J., 1998, 'The presence of Christ in the Eucharist and the formularies of the Church of England', Journal of Ecumenical Studies 35(2), 197-209.

Duncan, J.L., 2008, The attractions of the new perspective on Paul, viewed 10 April 2017, from http://www.tonybartolucci.com/reading/duncan.pdf

Dunn, J.D., 1990, Jesus, Paul and the law: Studies in Mark and Galatians, Westminster John Knox Press, Louisville, KY.

Episcopal Church in the USA, 1801, Anglican Online, viewed 10 April 2017, from http://anglicansonline.org/basics/thirty-nine_articles.html

Farnell, F.D., 2005, 'The new perspective on Paul: Its basic tenets, history and presuppositions', The Masters's Seminary Journal 16(2), 189-243.

Garlington, D., 2004, In defence of the new perspective on Paul: Essays and reviews, Wipf and Stock Publishers, Eugine.

Lambeth Conference, 2008, Section J: The Anglican Covenant (St. Andrew's Draft) viewed 10 April 2017, from http://www.anglicancommunion.org/resources/ document-library/lambeth-conference/2008/section-j-the-anglican-covenant-(stdocument-library/lambeth-conference/2008/section-j-the--
andrew's-draft)?author=Lambeth+Conference \&year $=2008$

Luther, M., 1543, On the Jews and their lies, viewed 10 April 2017, from http://vho. org/aaargh/fran/livres9/Luthereng.pdf

Martin, B.L., 2001, Christ and the law in Paul, Wipf and Stock, Eugine.

Murray, M., 2004, Playing a Jewish game: Gentle Christian Judaizing in the first and second centuries CE, Wilfrid Laurier University Press, Waterloo.

Perkins, P., 1978, New Testament Introduction, St Pauls, Mumbai.

Radner, E. \& Turner, P., 2006, The fate of the communion: The agony of Anglicanism and the future of the global church, WM B Eerdmans, Cambridge.

Rodgers, Jr, J., 2013, 'Salvation in the thirty-nine articles', Anglican Theological Review 95(1), 115-124.

Sanders, E.P., 1977, Paul and Palestinian Judaism: A comparison of patterns of religion, Fortress Press, Minneapolis, MN.

Stevens, L., 1989, 'Different voice/different voices: Anglican women in ministry', Review of Religious Research 30(3), 262-275.

Stoychev, T., 2011, 'Is there a new perspective on St. Paul's Theology?', Journal of European Baptist Studies 11(3), 31-50.

Szabados, A. (n.d.), Romans 3: 21-26: Traditional and 'New Perspective' Interpretations, viewed 10 April 2017, from http://szabadosadam.hu/divinity/wp-content/ uploads/2010/09/Paul-paper.pd 
Talbert, C.H., 2001, 'Paul, Judaism and the revisionists', Catholic Biblical Quarterly 63(1), 1-22.

The International Anglican Doctrinal and Theological Commission, 2008, Communion conflict and hope: The Kuala Lumpur report of the third inter-Anglican Theological and Doctrinal Commission, viewed 06 April 2017, from http://www. anglicancommunion.org/media/107645/IATDC-Inter-Anglican-Theological-andDoctrinal-Commission.pdf

Vanderbeck, R.M., Andersson, J., Valentine, G., Sadgrove, J. \& Ward, K., 2011 'Sexuality, activism, and witness in the Anglican communion: The 2008 Lambeth conference of Anglican bishops', Annals of the Association of American Geographers 101(3), 670-689.

Wright, N.T., 1988, 'Justification', in S.B. Ferguson, D.F. Wright \& P.J.I (eds.), New Dictionary of Theology, pp. 359-361, InterVarsity Press, Westmont, IL.

Wright, N.T., 1991, The climax of the covenant: Christ and the law in Pauline Theology, T\&T Clark, Edinburgh.

Wright, N.T., 1998, Paul's gospel and Caesar's empire, viewed 06 April 2017, from http://ntwrightpage.com/1998/01/01/pauls-gospel-and-caesars-empire/

Wright, N.T., 2002, Communion and Koinonia: Pauline reflections on tolerance and boundaries, viewed 06 April 2017, from http://ntwrightpage.com/2016/07/12/ communion-and-koinonia-pauline-reflections-on-tolerance-and-boundaries/
Wright, N.T., 2005a, Paul in different perspectives, viewed 31 March 2017, from http:// ntwrightpage.com/2005/01/03/paul-in-different-perspectives/

Wright, N.T., 2005b, Scripture and the authority of God: How to read the Bible today, HarperCollins, New York.

Wright, N.T., 2006, 'New Perspectives on Paul', in B.L. McCormack (ed.), Justification in perspective, pp. 243-264, Baker Academic, Grand Rapids, MI.

Wright, N.T., 2008, After GAFCON, viewed 06 April 2017, from http://ntwrightpage. com/2016/04/04/after-gafcon/

Wright, N.T., 2013, Pauline perspectives: Essays on Paul 1978-2013, Fortress Press, Minneapolis, MN.

Wright, N.T. (n.d.), Paul's Gospel and Caesar's Empire, viewed 10 April 2017, from http://ntwrightpage.com/1998/01/01/pauls-gospel-and-caesarsempire/

Wright, N.T. (n.d.), Paul in different perspectives, viewed 06 March 2017, from http:// ntwrightpage.com/2005/01/03/paul-in-different-perspectives/

Wright, T., 1980, 'Justification: The Biblical basis and its relevance for contemporary Evangelism', in T. Baker, G. Carey, J. Tiller \& T. Wright (eds.), The great acquittal: Justification by faith and current Christian thought, pp. 13-37, Fount Paperbacks, London. 